\title{
Vanadium Bioleaching Behavior by Acidithiobacillus ferrooxidans from a Vanadium-Bearing Shale
}

\author{
Dunpei Wei ${ }^{1,2,3}$, Tao Liu ${ }^{1,2,3, *}$, Yimin Zhang ${ }^{1,2,3,4}$, Zhenlei Cai ${ }^{1,2,3}$, Jingtao He ${ }^{1,2,3}$ and \\ Chengbao $\mathrm{Xu}{ }^{1,2,3}$ \\ 1 School of Resources and Environment Engineering, Wuhan University of Science and Technology, \\ Wuhan 430081, Hubei, China; wdp12621@126.com (D.W.); zym126135@126.com (Y.Z.); \\ ande559@163.com (Z.C.); HejingtaoCN@163.com (J.H.); xchb126@126.com (C.X.) \\ 2 Hubei Provincial Engineering Technology Research Center of High Efficient Cleaning Utilization for Shale \\ Vanadium Resource, Wuhan 430081, Hubei, China \\ 3 Hubei Collaborative Innovation Center for High Efficient Utilization of Vanadium Resources, Wuhan 430081, \\ Hubei, China \\ 4 School of Resources and Environmental Engineering, Wuhan University of Technology, Wuhan 430070, \\ Hubei, China \\ * Correspondence: liutao@wust.edu.cn; Tel.: +86-27-6886-2075
}

Received: 15 November 2017; Accepted: 11 January 2018; Published: 15 January 2018

\begin{abstract}
This study investigated bioleaching behavior of vanadium from a vanadium-bearing shale using Acidithiobacillus ferrooxidans (A. ferrooxidans). Results showed a maximum recovery of $62 \%$ vanadium in 1.2 -day bioleaching, which was $22.45 \%$ higher than the controls. Then, the vanadium leaching efficiency decreased significantly, only $24 \%$ of that was obtained on the tenth day. The vanadium extraction in 1.2 days was mainly attributed to the dissolution of vanadium in free oxides of shale. $\mathrm{Fe}^{3+}$ produced by A. ferrooxidans promoted the dissolution process. X-ray diffraction (XRD) patterns of the leached residues confirmed the generation of jarosite. SEM-EDS analysis of the residues indicated that jarosite adsorbed on the shale and inhibited the further dissolution of vanadium. The relevance of $\mathrm{V}, \mathrm{Fe}, \mathrm{S}, \mathrm{O}$ was quite good in the energy disperse $\mathrm{X}$-ray spectrometry (EDS) element mapping of jarosite, and acid-washing of the jarosite resulted in $31.6 \%$ of the vanadium in the precipitates desorption, indicating that the decrease of vanadium leaching efficiency in bioleaching process was caused by both adsorption and co-precipitation with jarosite.
\end{abstract}

Keywords: bioleaching; vanadium-bearing shale; jarosite; Acidithiobacillus ferrooxidans

\section{Introduction}

Vanadium, a significant rare metal, has gained extensive attention due to its widely industrial applications, especially in ferrous and nonferrous alloy productions, catalysts and batteries $[1,2]$. Vanadium-bearing shale is widely distributed in many southern provinces of China and is an important vanadium resource in China [3]. To meet the increasing demand of vanadium resources, vanadium extraction from vanadium-bearing shale has become essential.

Various processes for the extraction of $\mathrm{V}$ from vanadium-bearing shale have been reported. Conventional chemical techniques include additives roasting-water leaching or low acidity leaching, direct acid leaching and low salt roasting-cyclic oxidation [4,5]. However, these methods for vanadium recovery have the disadvantages of a large amount of additives or acid consumption and the generation of hazardous wastes [6-8]. The increasing environmental concerns limit the application of these techniques. Therefore, it is essential to develop new technologies for extracting vanadium from vanadium-bearing shale with higher economic efficiency and lower pollution. 
Compared to the conventional techniques, the biotechnological leaching process offers attractive features for metal extraction from solid materials. It has been proven to be an effective, low-cost and eco-friendly way to process various minerals and wastes [9-12]. It is based on the interaction of microorganisms with metal sources for the transformation of organic or inorganic acids (protons), oxidation and reduction reactions and the excretion of complexing agents [13]. Acidithiobacillus ferrooxidans (A. ferrooxidans), which can utilize elemental sulfur and ferrous sulfate for growth and produce sulfuric acid, is one of the most prominent bioleaching microorganisms [14].

In general, most of the vanadium in shale is scattered in mica minerals as the isomorphism state, and scattered in free oxides and carbonaceous materials as the sorption state [15]. In a number of studies using $A$. ferrooxidans, the feasibility of bioleaching of different metals from silicate minerals was shown in lab-scale. Metals in these minerals are mainly leached via sulfuric acid and ferric ion produced by microorganisms [16-18]. To promote the growth of microorganisms and the production of metabolites, the addition of extra energy source (sulfur, ferrous sulfate, etc.) into the leaching culture is needed. Iveta Štyriaková et al. [19] studied the bioleaching of phlogopite $\left(\mathrm{K}_{2}\left(\mathrm{Si}_{6} \mathrm{Al}_{2}\right) \mathrm{Mg}_{6} \mathrm{O}_{20}(\mathrm{OH})_{4}\right)$ with A. ferrooxidans and a solution of $1550 \mathrm{mg} / \mathrm{L} \mathrm{Mg}$ was obtained. Tariq M. Bhatti et al. [20,21] investigated the structural alteration of phlogopite and biotite $\left(\mathrm{K}\left(\mathrm{Mg}, \mathrm{Fe}^{2+}\right)_{3} \mathrm{AlSi}_{3} \mathrm{O}_{10}(\mathrm{OH}, \mathrm{F})_{2}\right)$ during weathering by $A$. ferrooxidans, finding that both minerals were partly altered to vermiculite when ferrous sulfate was added as an energy source because the formation of jaroite caused selective loss of $\mathrm{K}^{+}$from interlayer positions of minerals, and no structural alterations were detected when adding sulfur as the energy source. The studies about bioleaching of vanadium are focused on the recovery of vanadium from industrial wastes such as spent catalysts and slag fly ash, in which vanadium exists as oxides, and considerable vanadium recovery ( $80 \%-100 \%)$ was obtained when bioleaching of these wastes by $A$. ferrooxidans [22-24] occurred. Mei-xia Liao et al. [25] studied bioleaching of vanadium from stone coal using $A$. ferrooxidans, and vanadium extraction of $69 \%$ was obtained in 25 days. However, there is very few little research on bioleaching of vanadium from vanadium-bearing shale.

In the present study, bioleaching of vanadium-bearing shale was carried out using adapted A. ferrooxidans, and the effects of initial $\mathrm{pH}$, pulp density, initial $\mathrm{Fe}^{2+}$ concentration, inoculum percentage and leaching time were evaluated to optimize the process parameters. Using the bioleaching process without any inoculum as a control, the contribution of A. ferrooxidans on vanadium solubilization was investigated. X-ray diffraction (XRD) and scanning electron microscopy-energy disperse X-ray spectrometry (SEM-EDS) analysis were conducted to reveal the vanadium bioleaching behavior.

\section{Materials and Methods}

\subsection{Materials}

The vanadium-bearing shale was obtained from Shiyan, Hubei Province, China. The shale was decarbonized in muffle furnace at $750{ }^{\circ} \mathrm{C}$ for $30 \mathrm{~min}$. The obtained ore was referred to as raw ore throughout this work. The ore sample was sterilized by steam autoclaving at $121^{\circ} \mathrm{C}$ for 20 min to ensure the absence of external bacterial contamination. All of the reagents used in this study were in analytical grade. The aqueous solutions were prepared using deionized water.

\subsection{Microorganism and Culture Medium}

A pure strain of Acidithiobacillus ferrooxidans $(11,477)$ was purchased from the German Collection of Microorganisms and Cell Cultures (DSMZ) (Braunschweig, Germany). The 9K medium used for cell cultivation consisted of the following components: $3.0 \mathrm{~g} / \mathrm{L}\left(\mathrm{NH}_{4}\right)_{2} \mathrm{SO}_{4}, 0.1 \mathrm{~g} / \mathrm{L} \mathrm{KCl}, 0.5 \mathrm{~g} / \mathrm{L}$ $\mathrm{MgSO}_{4} \cdot 7 \mathrm{H}_{2} \mathrm{O}, 0.5 \mathrm{~g} / \mathrm{L} \mathrm{K}_{2} \mathrm{HPO}_{4}$ and $0.01 \mathrm{~g} / \mathrm{L} \mathrm{Ca}\left(\mathrm{NO}_{3}\right)_{2}$. Then, $44.7 \mathrm{~g} / \mathrm{L} \mathrm{FeSO} 4 \cdot 7 \mathrm{H}_{2} \mathrm{O}$ was added as the energy source. The culture of $A$. ferrooxidans was incubated in $250 \mathrm{~mL}$ Erlenmeyer flask containing $100 \mathrm{~mL}$ of the medium and $10 \%(v / v)$ inoculum, on a rotary shaker at $150 \mathrm{rpm}$ at constant temperature of $30{ }^{\circ} \mathrm{C}$. The initial $\mathrm{pH}$ of the culture was adjusted to 2.0 with sulfuric acid. 
Prior to bioleaching, the bacterial strain was acclimatized to the vanadium-bearing shale over a prolonged adaptation period. The adaptation period began using $9 \mathrm{~K}$ medium with $10 \mathrm{~g} / \mathrm{L}$ raw ore. When the cells were at the end of the logarithmic phase, $10 \mathrm{~mL}$ cells' culture was inoculated to $90 \mathrm{~mL}$ 9K medium with higher pulp density. Once there was no improvement in bacterial growth, the adaptation process stopped.

\subsection{Bioleaching Experiment}

The cells toward the end of the logarithmic phase were harvested by centrifugation at $10,000 \times g$ for $10 \mathrm{~min}$. The cells were washed with acidified distilled water $\mathrm{pH} 2.0$ and were finally resuspended in sterile $9 \mathrm{~K}$ medium to an initial density of $1 \times 10^{8}$ cells $/ \mathrm{mL}$ to serve as inoculum. All experiments were performed in a $250 \mathrm{~mL}$ Erlenmeyer flask with a working volume of $100 \mathrm{~mL}$. The flasks were incubated at $30^{\circ} \mathrm{C}$, shaken at $150 \mathrm{rpm}$. Samples were taken every day, and the supernatant was used to determine concentrations of vanadium and iron. Sampling loss was supplemented with the same volume of basic culture medium (9K medium without ferrous sulfate).

\subsection{Analytical Methods}

The mineralogical compositions of solid samples were identified by X-ray diffraction (XRD, D/MAX 2500PC, Rigaku, Tokyo, Japan) using $\mathrm{Cu} \mathrm{K} \alpha$ radiation. Microscopic observation and analysis of elemental distribution in samples were conducted by scanning electron microscopy (JSM-6610)(JEOL Co., Tokyo, Japan) equipped with an energy disperse X-ray spectrometry (Bruker, Karlsruhe, Germany). The distribution of vanadium in solid samples was carried out according to the sequential extraction procedures [26]. The vanadium concentration was analyzed by ferrous ammonium sulphate titration (GB/T 8704.5-2007) [27]. The total Fe (TFe) and $\mathrm{Fe}^{2+}$ concentration was ascertained by means of O-phenanthroline spectrophotometry (HJ/T 345-2007) [28], and the contents of $\mathrm{Fe}^{3+}$ were calculated from the difference between the contents of total $\mathrm{Fe}$ and $\mathrm{Fe}^{2+}$. The $\mathrm{pH}$ of the supernatant was measured with a pH meter (PHS-3C) (Shanghai INESA Scientific Instrument Co. Ltd., Shanghai, China).

The vanadium leaching efficiency was taken as index and calculated using the following equation:

$$
\eta=\frac{C \cdot V}{\alpha \cdot m} \times 100 \%
$$

where $\eta$ is the vanadium leaching efficiency $(\%), V$ is the leachate volume $(\mathrm{mL}), C$ is the vanadium concentration in leachate $(\mathrm{g} / \mathrm{mL}), m$ is the mass of shale $(\mathrm{g})$, and $\alpha$ is the vanadium content in shale (wt \%).

\section{Results and Discussion}

\subsection{Material Characterization}

The main chemical compositions of the ore sample are shown in Table 1 . It can be seen that $\mathrm{Si}$ $(41.82 \%), \mathrm{Al}(1.45 \%), \mathrm{Fe}(1.14 \%)$, and $\mathrm{V}(0.73 \%)$ are the major elements. The XRD pattern of the sample shown in Figure 1 indicates that the main mineral phases are quartz, hematite, barite and feldspar.

Table 1. Main chemical compositions of raw sample (wt \%).

\begin{tabular}{ccccccccc}
\hline Element & V & Fe & Si & Al & K & S & Ca & Mg \\
\hline Content, wt \% & 0.73 & 1.14 & 41.82 & 1.45 & 0.67 & 0.55 & 1.04 & 0.37 \\
\hline
\end{tabular}




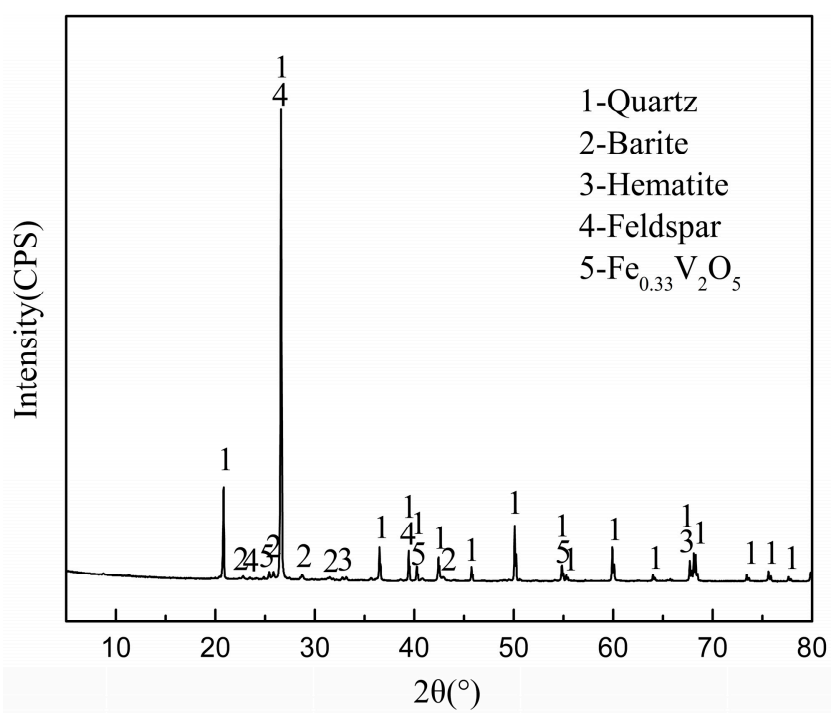

Figure 1. X-ray diffraction (XRD) image of the ore sample.

The elemental distribution of raw ore is shown in Figure 2. It shows that the relevance of $\mathrm{V}, \mathrm{Si}$, $\mathrm{O}, \mathrm{Al}$ and $\mathrm{K}$ was quite good, indicating that vanadium probably existed in silicoaluminate minerals. The distribution of vanadium in raw ore is shown in Table 2. The result indicated that $63.87 \%$ of vanadium was bound to free oxides, $32.35 \%$ of vanadium existed in silicoaluminate minerals and $3.78 \%$ in the residual carbonaceous materials.

Table 2. Distribution of vanadium in the sample (wt \%).

\begin{tabular}{cccc}
\hline Total Vanadium & Bound to Free Oxides & Silico-Aluminate & Bound to Organic \\
\hline 100 & 63.87 & 32.35 & 3.78 \\
\hline
\end{tabular}

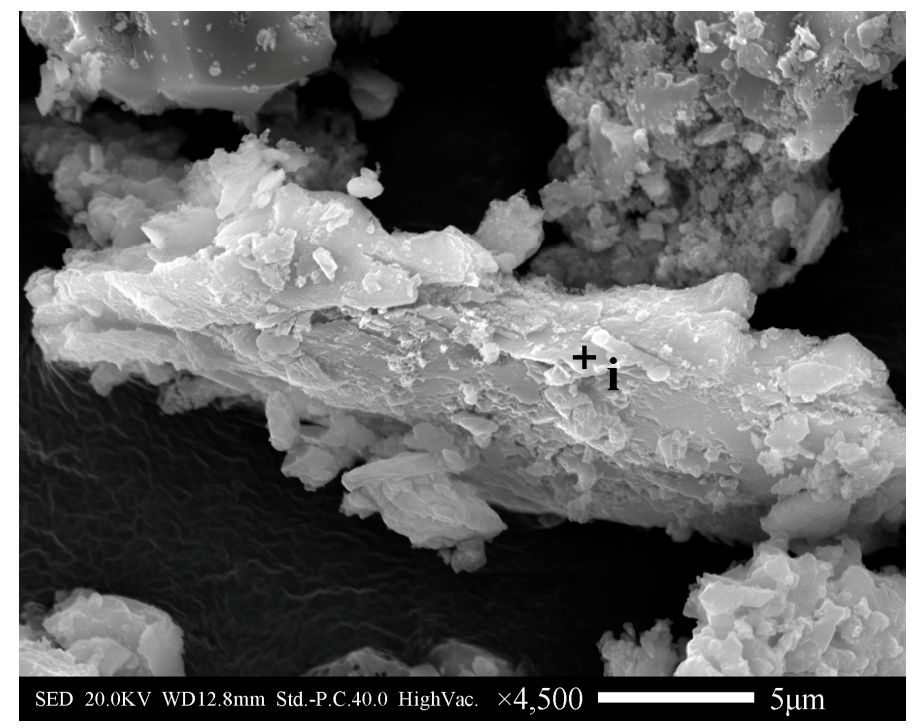

Figure 2. Cont. 


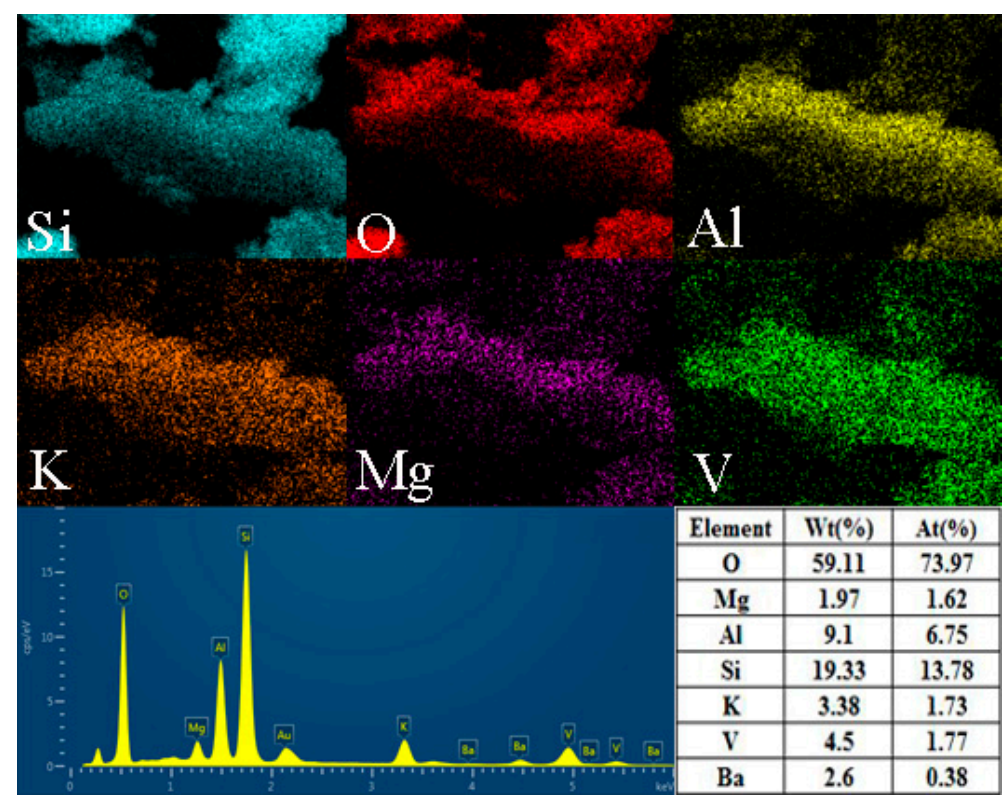

Figure 2. Scanning electron microscopy (SEM) images with energy disperse X-ray spectrometry (EDS) element mapping of the raw ore and the elemental weight percent $(\mathrm{Wt}(\%))$ and atoms percent $(\mathrm{At}(\%))$ at point i.

\subsection{Main Affecting Factors}

\subsubsection{Effect of Initial $\mathrm{pH}$}

The initial $\mathrm{pH}$ is an important factor affecting the leaching process. The optimal $\mathrm{pH}$ for the growth of A. ferrooxidans is around 2.0, and it is easier for the dissolution of shale at lower $\mathrm{pH}$ values. Thus, it is essential to ascertain the optimal initial $\mathrm{pH}$. The effect of initial $\mathrm{pH}$ was tested at values of 1.3, $1.5,1.7,2.0,2.3$ and 2.5 with $10 \%(v / v)$ inoculum as described above, $20 \mathrm{~g} / \mathrm{L}$ pulp density and $9 \mathrm{~g} / \mathrm{L}$ initial $\mathrm{Fe}^{2+}$ concentration. Control tests, without any microorganism inoculation, were performed in the same condition as for the bioleaching.

Figure 3 shows the variation of the vanadium leaching efficiency over time at different $\mathrm{pH}$ values in the bioleaching process. As shown in Figure 3, the vanadium leaching efficiency increased in the first day, which increased more remarkably when $\mathrm{pH}$ was above 2.0. However, a significant decrease for vanadium recovery was observed after the first leaching day, and it decreased to $30 \%-40 \%$ on the 10th day. Vanadium leaching efficiency decreased as initial $\mathrm{pH}$ increased. $\mathrm{H}^{+}$is important in the dissolution of vanadium-bearing shale, and the shale may dissolve easier at lower $\mathrm{pH}$. In addition, at higher $\mathrm{pH}$ values, the chance of iron precipitation is higher and the available $\mathrm{Fe}^{3+}$ in the solution is less. Furthermore, the precipitate may produce an additional product layer over the reactant. The highest extraction was $68.86 \%$ at $\mathrm{pH}=1.3$, leaching for one day. However, vanadium leaching efficiency of the control test at $\mathrm{pH}=1.3$ was $66.09 \%$, and only $2.77 \%$ of the vanadium leaching efficiency was improved, while the vanadium leaching efficiency increased from $32.65 \%$ (control) to $54.15 \%$ (inoculated) at $\mathrm{pH}=2.5$. It is noted that the dissolution of vanadium is mainly due to $\mathrm{H}^{+}$when $\mathrm{pH}$ is less than 1.7, and the inoculum has a more significant effect on vanadium extraction at higher $\mathrm{pH}$ values. Considering the acid consumption and effect of $A$. ferrooxidans on vanadium extraction, 2.0 was selected as the optimal initial $\mathrm{pH}$ in the subsequent tests. 

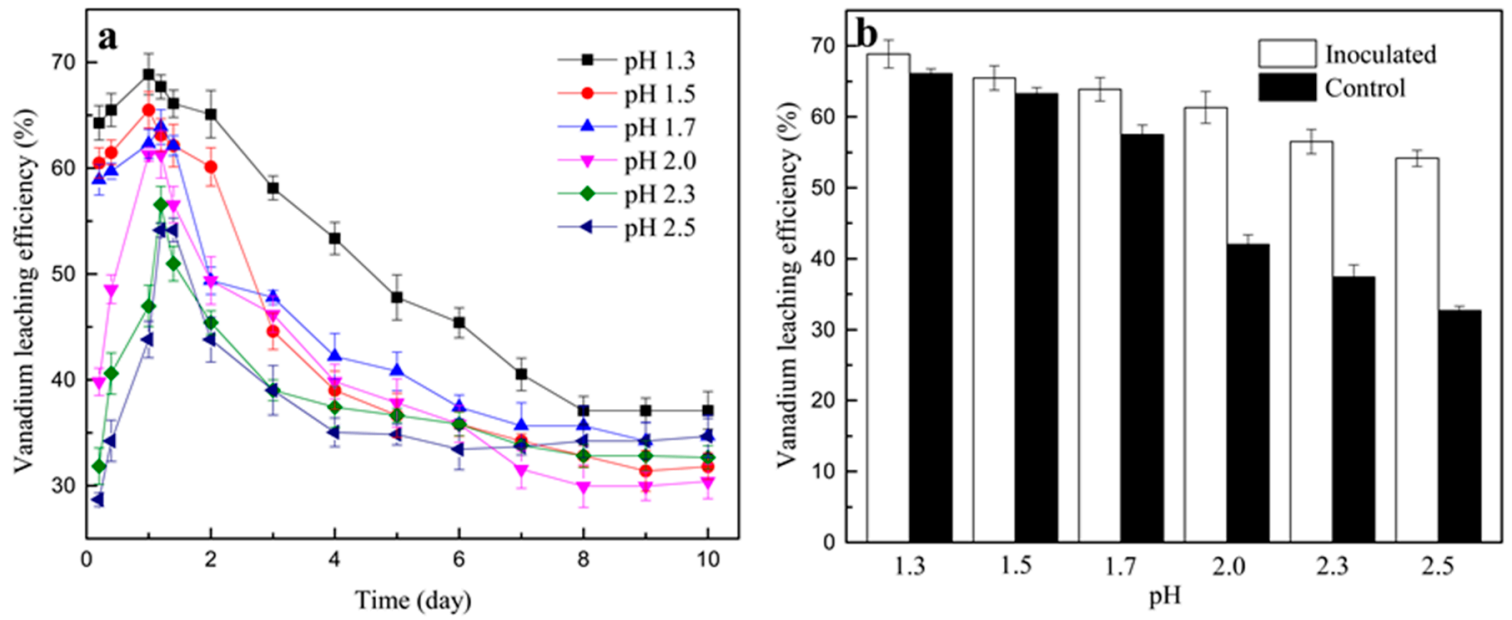

Figure 3. Vanadium leaching efficiency (a) and the highest vanadium leaching efficiency of the inoculated tests and that of the control tests $(\mathbf{b})$ at different $\mathrm{pH}$.

\subsubsection{Effect of Pulp Density}

The effect of pulp density was studied at $5,10,20,30,50,70 \mathrm{~g} / \mathrm{L}$. The vanadium leaching efficiency was found to be at a maximum on day 1 when the pulp density was $5-50 \mathrm{~g} / \mathrm{L}$, while it was observed in two days when the pulp density was $70 \mathrm{~g} / \mathrm{L}$. The bacterial activity can be evaluated indirectly through iron oxidation rate. $\mathrm{Fe}^{2+}$ was completely oxidized in two days at a different pulp densities. This indicated that the increase of pulp density has a minimal impact on the activity of the adapted A. ferrooxidans. The highest vanadium leaching efficiency of different pulp density over time is shown in Figure 4. The results indicated that vanadium leaching efficiency decreased with the increase of pulp density. About $61 \%-63 \%$ of vanadium has been leached from vanadium-bearing shale when pulp density was less than $20 \mathrm{~g} / \mathrm{L}$. Further increasing pulp density, vanadium leaching efficiency decreased markedly. In order to gain the maximum processing capacity, the pulp density of $20 \mathrm{~g} / \mathrm{L}$ was appropriate.

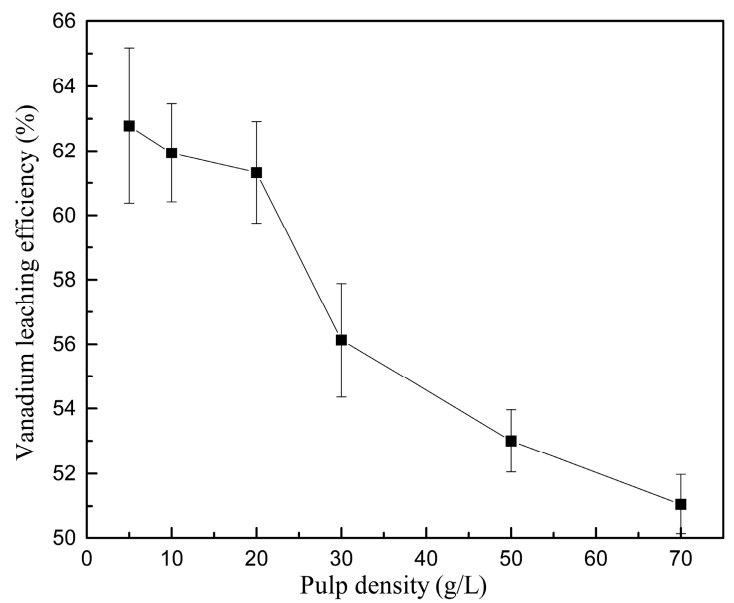

Figure 4. The highest vanadium leaching efficiency over time at different pulp densities.

\subsubsection{Effect of Initial $\mathrm{Fe}^{2+}$ Concentration}

Figure 5 represents the effect of initial $\mathrm{Fe}^{2+}$ concentration from 1 to $11 \mathrm{~g} / \mathrm{L}$ in the culture medium on vanadium leaching efficiency. It can be seen that the vanadium leaching efficiency increased as the initial $\mathrm{Fe}^{2+}$ in the culture medium increased up to $5 \mathrm{~g} / \mathrm{L}$, above which vanadium leaching efficiency decreased slightly. Initial $\mathrm{Fe}^{2+}$ concentration is necessary for the bacterial growth in the bioleaching 
process. However, it was supposed that at higher initial $\mathrm{Fe}^{2+}$ concentration, the iron precipitation rate increased, thereby creating an additional diffusion barrier and leading to a decreased leaching rate [29]. Thus, the optimal initial $\mathrm{Fe}^{2+}$ was determined to be $5 \mathrm{~g} / \mathrm{L}$ in the culture medium.

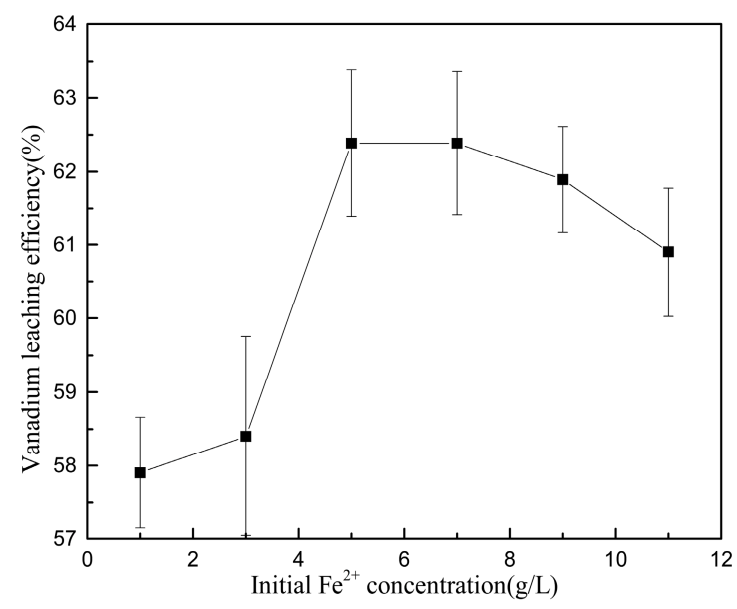

Figure 5. The highest vanadium leaching efficiency over time at different initial $\mathrm{Fe}^{2+}$ concentrations.

\subsubsection{Effect of Inoculum Percentage}

The effect of inoculum percentage from $5 \%$ to $20 \%$ on vanadium leaching efficiency is shown in Figure 6. Vanadium leaching efficiency remained nearly constant as inoculum percentage increased from $5 \%$ to $20 \%$, while the time needed for vanadium leaching efficiency to reach its maximum decreased as it increased from $5 \%$ to $20 \%$. It can be seen that more inoculums can accelerate the bioleaching rate. It is generally accepted that $A$. ferrooxidans mediates bioleaching of minerals through the contact and indirect mechanisms. The contact mechanism usually requires a few days to work out. The indirect mechanism occurs by sulfuric acid and $\mathrm{Fe}^{3+}$ produced by the microbe. In addition, 1.5 days were taken to obtain highest vanadium leaching efficiency, which did not follow the contact mechanism. Sulfuric acid has not been produced in this period. It was supposed that vanadium extraction followed the indirect mechanism, namely, $\mathrm{Fe}^{3+}$ produced by A. ferrooxidans promoted the dissolution of vanadium-bearing shale. Increasing the inoculum percentage could accelerate the oxidation of ferrous iron, resulting in more ferric irons in a short time, thus accelerating the bioleaching rate.

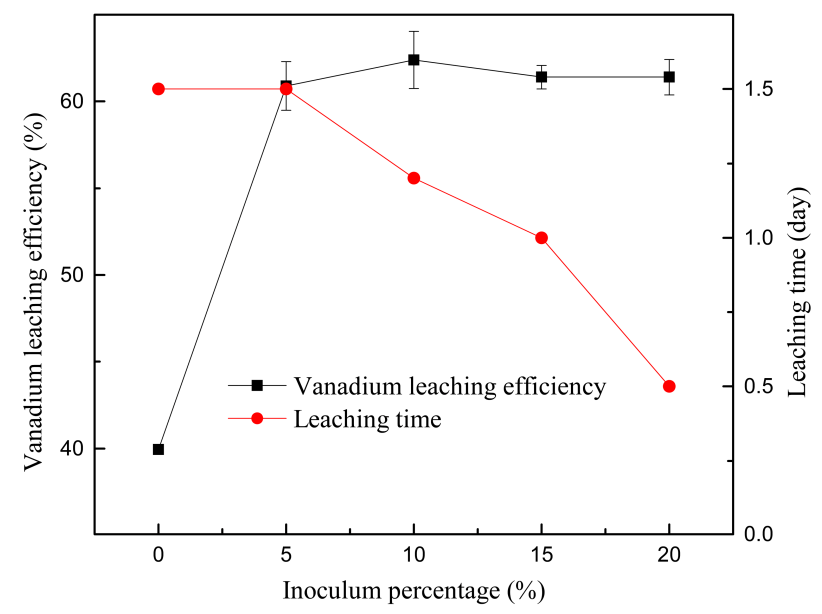

Figure 6. The highest vanadium leaching efficiency over time and the time needed for vanadium leaching efficiency to reach their maximum at different inoculum percentage. 


\subsubsection{Effect of Leaching Time}

Figure 7 shows the vanadium leaching efficiency with change of $\mathrm{pH}$, the concentrations of $\mathrm{Fe}^{3+}$ and $\mathrm{Fe}^{2+}$ under optimal conditions by leaching time. The trend of vanadium leaching efficiency over time was similar to the variation of $\mathrm{pH}$ values. In the first 1.2 days of the bioleaching, $\mathrm{Fe}^{2+}$ was completely oxidized to $\mathrm{Fe}^{3+}$ by A. ferrooxidans (Equation (1)), resulting in $\mathrm{pH}$ increased from 2.0 to 2.39. The decrease of ferrous concentration in control group was probably due to the air. There is no difference in the concentration of TFe between inoculated and control group, indicating that the hydrolysis polymerization of $\mathrm{Fe}^{3+}$ produced by A. ferrooxidans has not yet occurred. $\mathrm{Fe}^{3+}$ concentration of the inoculated increased to $4.2 \mathrm{~g} / \mathrm{L}$, while it was below $0.5 \mathrm{~g} / \mathrm{L}$ in the control test. Meanwhile, vanadium leaching efficiency increased from $35.45 \%$ to $62.39 \%$, and $22.45 \%$ of vanadium leaching efficiency was improved compared to the control group. This may accordingly be the consequence of strong oxidising environment created by high $\mathrm{Fe}^{3+}$ concentration. After leaching for 1.2 days, $\mathrm{pH}$ and the concentration of $\mathrm{Fe}^{3+}$ decreased significantly due to the formation of $\mathrm{K}^{+}$-jarosite (Equation (2)), and $\mathrm{NH}_{4}{ }^{+}$-jarosite (Equation (3)). Meanwhile vanadium leaching efficiency decreased, which was supposed to be caused by the adsorption or co-precipitation with jarosite:

$$
\begin{gathered}
4 \mathrm{Fe}^{2+}+4 \mathrm{H}^{+}+\mathrm{O}_{2} \stackrel{\text { A. ferrooxidans }}{\rightarrow} 4 \mathrm{Fe}^{3+}+2 \mathrm{H}_{2} \mathrm{O} \\
3 \mathrm{Fe}^{3+}+2 \mathrm{SO}_{4}^{2-}+6 \mathrm{H}_{2} \mathrm{O}+\mathrm{K}^{+} \rightarrow \mathrm{KFe}_{3}\left(\mathrm{SO}_{4}\right)_{2}(\mathrm{OH})_{6}+6 \mathrm{H}^{+} \\
3 \mathrm{Fe}^{3+}+2 \mathrm{SO}_{4}^{2-}+6 \mathrm{H}_{2} \mathrm{O}+\mathrm{NH}_{4}^{+} \rightarrow\left(\mathrm{NH}_{4}\right) \mathrm{Fe}_{3}\left(\mathrm{SO}_{4}\right)_{2}(\mathrm{OH})_{6}+6 \mathrm{H}^{+}
\end{gathered}
$$
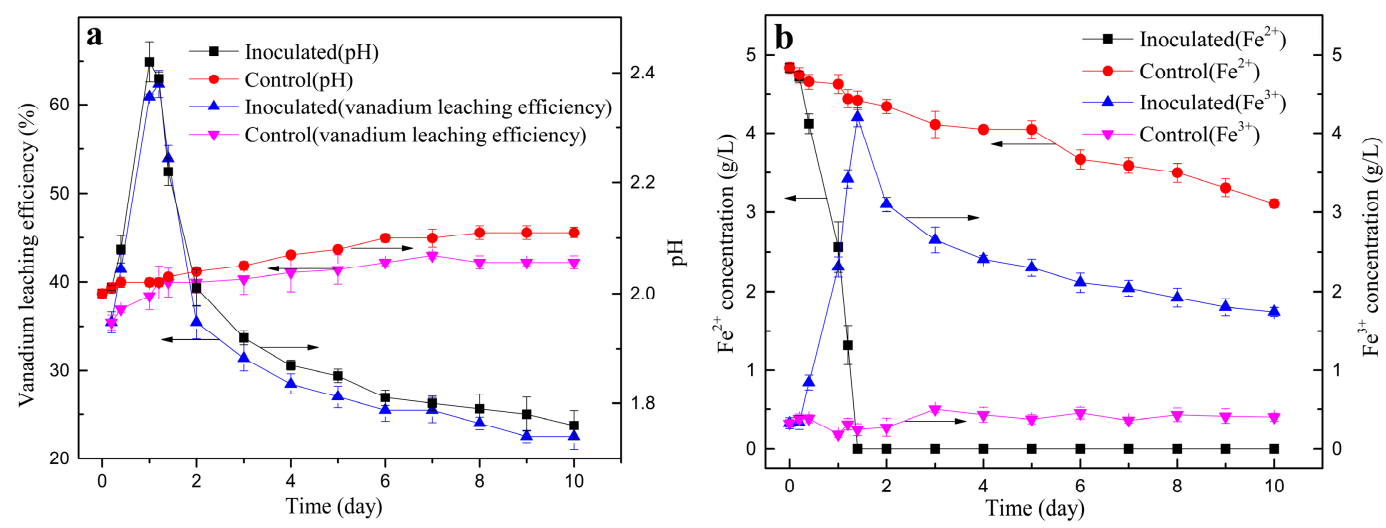

Figure 7. Vanadium leaching efficiency and $\mathrm{pH}(\mathbf{a})$, the concentrations of $\mathrm{Fe}^{3+}$ and $\mathrm{Fe}^{2+}(\mathbf{b})$ in leach liquors during the bioleaching of vanadium-bearing shale.

\subsection{Vanadium Bioleaching Behavior}

The XRD analysis of raw ore, bioleaching residues obtained after 1.2 days and 10 days are shown in Figure 8. Quartz, hematite and barite remained resistant to any structural alteration during the leaching process. The diagnostic diffraction peaks of $\mathrm{Fe}_{0.33} \mathrm{~V}_{2} \mathrm{O}_{5}$ were absent from the leach residue after leaching for 1.2 days. The distribution of vanadium in the residue was detected. Furthermore, it was found that vanadium in free oxides decreased from $63.87 \%$ to $8.9 \%$ after leaching for 1.2 days, illustrating that the increase of vanadium leaching efficiency in 1.2 days was mainly due to the dissolution of vanadium in free oxides. Jarosite formation was only detected in the leached residue after leaching for 10 days. Silicate minerals in vanadium-bearing shale are layer silicates that usually contain $\mathrm{K}^{+}$in the interlayer position. $\mathrm{Fe}^{3+}$ is invariably released into the leach solution during bioleaching processes, which may precipitate in the form of potassium jarosite $\left(\mathrm{KFe}_{3}\left(\mathrm{SO}_{4}\right)_{2}(\mathrm{OH})_{6}\right)[30]$. 


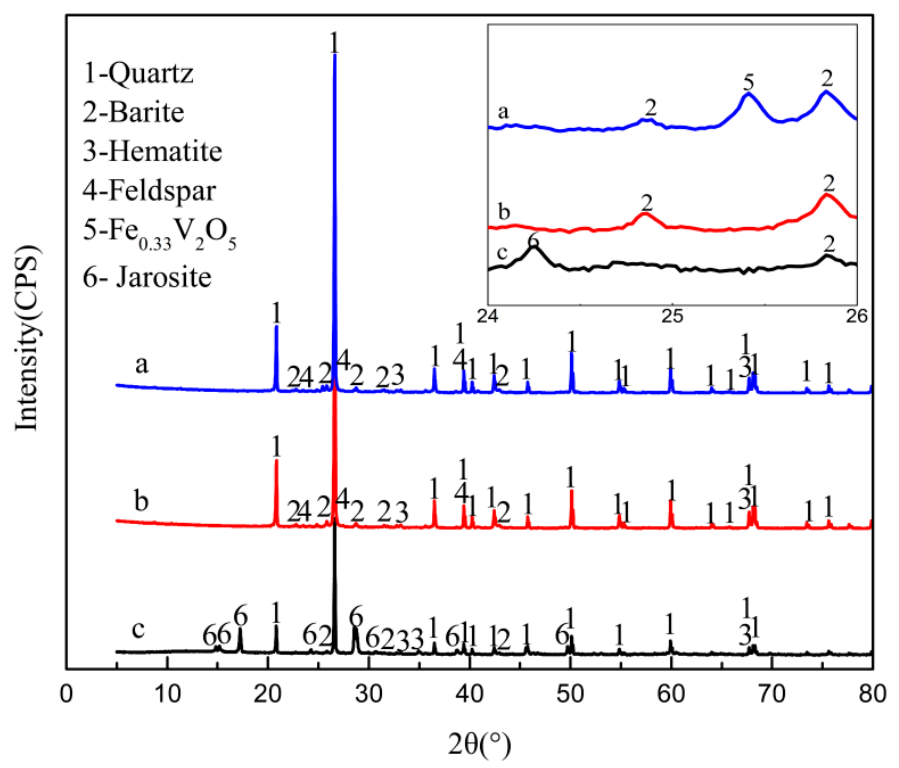

Figure 8. XRD patterns of raw ore and leached residues. (a) raw ore, (b) residue obtained after 1.2 days and (c) residue obtained after 10 days.

SEM-EDS analysis of leached residue obtained after 10 days was conducted and the results are presented in Figure 9. As shown in Figure 9a, the precipitate consisted of dominant cauliflower-like masses. Figure $9 \mathrm{~b}$ shows the EDS element mapping of one of the particles. Si, O, S, Fe, K, N, Al and V had a good relevance in the view fields from the SEM-EDS elemental mapping images. Combined with the XRD analysis of the leached residue, the particle consisted of jarosite and silicoaluminate minerals in the raw ore. It was assumed that jarosite absorbed on the ore surface during the leaching process, and formed a passivation layer, resulting in few vanadium released into the leaching solution even when the $\mathrm{pH}$ decreased.

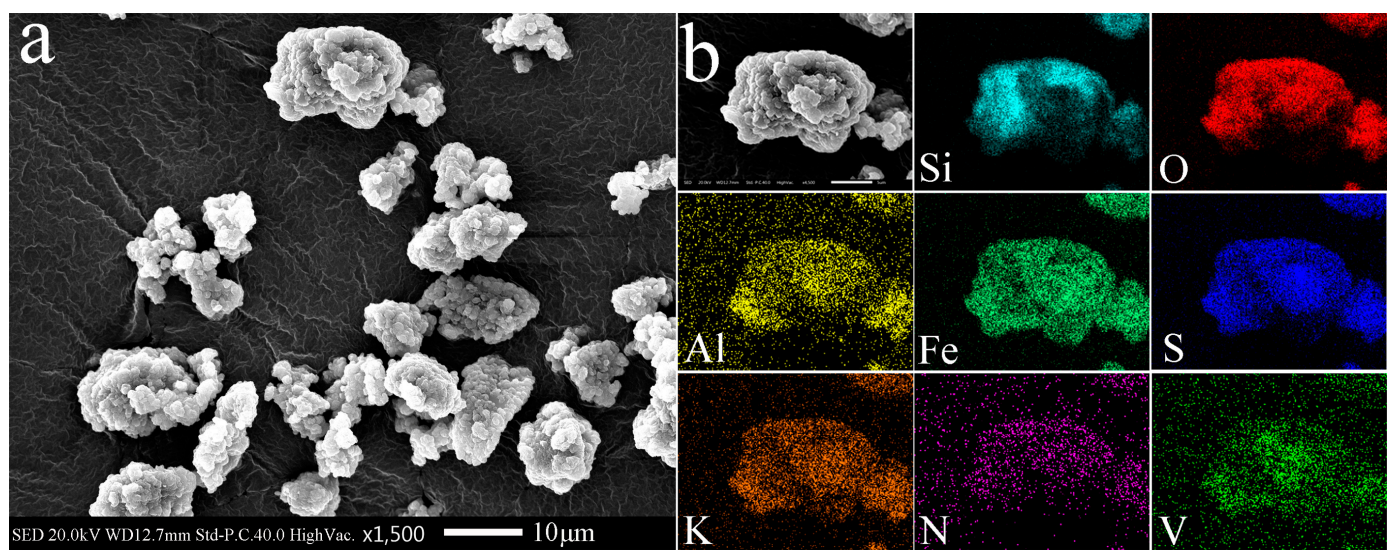

Figure 9. SEM images (a) and EDS element mapping (b) of leached residues.

Research about the removal of vanadium from aqueous solutions has indicated that vanadium can be effectively removed by co-precipitation with iron (III) [31,32]. The removal mechanism of vanadium could be explained by a formal co-precipitation intended as the incorporation of vanadium in the iron particles formed by the addition of iron (III) and/or adsorption of vanadium on the iron (hydr)oxides surface [33]. To prove the adsorption or co-precipitation of vanadium and jarosite, the leachate was filtrated after leaching for 1.2 days, and the filtrate was put back to rotary shaker, shaken at $30{ }^{\circ} \mathrm{C}$ and $150 \mathrm{rpm}$ until precipitates were formed. SEM-EDS analysis of the precipitates was conducted and the 
results are shown in Figure 10. The results indicated that the elemental distribution of $\mathrm{O}, \mathrm{S}, \mathrm{Fe}, \mathrm{K}$ and $\mathrm{N}$ had obvious relevance, indicating that the precipitates consist of ammonium jarosite and potassium jarosite. Meanwhile, the relevance of $\mathrm{V}, \mathrm{O}, \mathrm{S}$, and Fe indicated that the vanadium indeed existed in jarosite. Sarita H. Ahoranta et al. [34] adopted a simple approach to distinguish metals' adsorption from co-precipitation with jarosite. Washing precipitates with dilute acid, metals adsorbed by jarosite may be released to the liquid phase. In this research, acid-washing of the jarosite (with de-ionised water adjusted to $\mathrm{pH} 1.0$ with concentrated $\mathrm{H}_{2} \mathrm{SO}_{4}$ ) resulted in $31.6 \%$ of vanadium in the precipitates desorption, indicating that most of the vanadium was co-precipitated. These results indicated that the decrease of vanadium content in leachate was caused by both adsorption and co-precipitation.
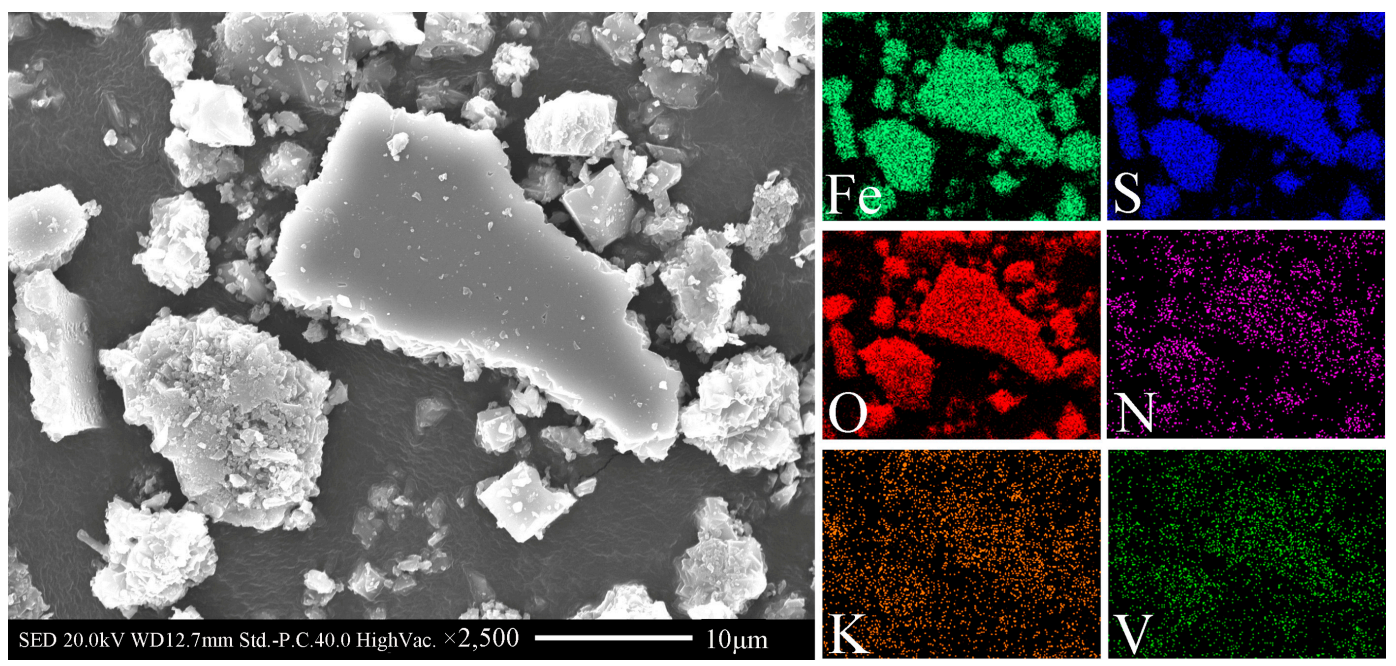

Figure 10. SEM images with EDS element mapping of jarosite generated in leaching solution.

It is worthwhile to further investigate the correlation between jarosite and vanadium during bioleaching. More work is required to reduce the formation of jarosite during bioleaching of vanadium-bearing shale.

\section{Conclusions}

Bioleaching of a vanadium-bearing shale was studied using $A$. ferrooxidans. The best conditions for vanadium extraction were $20 \mathrm{~g} / \mathrm{L}$ pulp density, $5 \mathrm{~g} / \mathrm{L}$ initial $\mathrm{Fe}^{2+}$ and $10 \%$ inoculum percentage under $\mathrm{pH}$ 2.0. The vanadium leaching efficiency of $62 \%$ was achieved in 1.2 days. Then, the vanadium leaching efficiency decreased to $24 \%$ in 10 days. Results showed that chemical controls were not as effective as the inoculated cultures. $\mathrm{Fe}^{3+}$ produced by $A$. ferrooxidans accelerated the vanadium dissolution in the bioleaching process.

The increase of vanadium recovery is mainly due to the dissolution of vanadium in free oxides, as the vanadium content in free oxides of shale decreased from $63.87 \%$ to $8.9 \%$ in 1.2 days' bioleaching. EDS analysis of jarosite showed that vanadium indeed existed in jarosite, and the formation of jarosite led to the decrease of vanadium leaching efficiency. Acid-washing of jarosite resulted in $31.6 \%$ of vanadium being desorbed from the precipitates. These results suggested that the decrease of vanadium leaching efficiency was caused by both adsorption and co-precipitation with jarosite.

Further experiments should be conducted to investigate the bioleaching mechanism of vanadium-bearing shale and the correlation between jarosite and vanadium in the lixivium. Corresponding measures should be taken to increase vanadium leaching efficiency.

Acknowledgments: This research was financially supported by the National Natural Science Foundation of China (No. 51474162, No. 51604197 \& No. 51774216). 
Author Contributions: Dunpei Wei, Zhenlei Cai and Tao Liu conceived and designed the experiments; Dunpei Wei, Jingtao He, and Chengbao Xu performed the experiments; Dunpei Wei and Zhenlei Cai analyzed the data; Tao Liu and Yimin Zhang contributed reagents/materials/analysis tools; and Dunpei Wei wrote this paper.

Conflicts of Interest: The authors declare no conflict of interest.

\section{References}

1. Yamamura, T.; Wu, X.; Ohta, S.; Shirasaki, K.; Sakuraba, H.; Satoh, I.; Shikama, T. Vanadium solid-salt battery: Solid state with two redox couples. J. Power Sources 2011, 196, 4003-4011. [CrossRef]

2. Imtiaz, M.; Rizwan, M.S.; Xiong, S.; Li, H.; Ashraf, M.; Shahzad, S.M.; Shahzad, M.; Rizwan, M.; Tu, S. Vanadium, recent advancements and research prospects: A review. Environ. Int. 2015, 80, 79-88. [CrossRef] [PubMed]

3. Zhang, Y.M.; Bao, S.X.; Liu, T.; Chen, T.J.; Huang, J. The technology of extracting vanadium from stone coal in China: History, current status and future prospects. Hydrometallurgy 2011, 109, 116-124. [CrossRef]

4. Cai, Z.; Zhang, Y.; Liu, T.; Huang, J. Mechanisms of Vanadium Recovery from Stone Coal by Novel $\mathrm{BaCO}_{3} / \mathrm{CaO}$ Composite Additive Roasting and Acid Leaching Technology. Minerals 2016, 6, 26. [CrossRef]

5. Wang, F.; Zhang, Y.M.; Liu, T.; Huang, J.; Zhao, J.; Zhang, B.-G.; Liu, J. Comparison of direct acid leaching process and blank roasting acid leaching process in extracting vanadium from stone coal. Int. J. Miner. Process. 2014, 128, 40-47. [CrossRef]

6. He, D.; Feng, Q.; Zhang, G.; Ou, L.; Lu, Y. An environmentally-friendly technology of vanadium extraction from stone coal. Miner. Eng. 2007, 20, 1184-1186. [CrossRef]

7. Xue, N.; Zhang, Y.; Liu, T.; Huang, J.; Liu, H.; Chen, F. Mechanism of vanadium extraction from stone coal via hydrating and hardening of anhydrous calcium sulfate. Hydrometallurgy 2016, 166, 48-56. [CrossRef]

8. Yuan, Y.; Zhang, Y.; Liu, T.; Chen, T. Comparison of the mechanisms of microwave roasting and conventional roasting and of their effects on vanadium extraction from stone coal. Int. J. Miner. Metall. Mater. 2015, 22, 476-482. [CrossRef]

9. Zhao, H.; Wang, J.; Gan, X.; Zheng, X.; Tao, L.; Hu, M.; Li, Y.; Qin, W.; Qiu, G. Effects of pyrite and bornite on bioleaching of two different types of chalcopyrite in the presence of Leptospirillum ferriphilum. Bioresour. Technol. 2015, 194, 28-35. [CrossRef] [PubMed]

10. Li, S.; Zhong, H.; Hu, Y.; Zhao, J.; He, Z.; Gu, G. Bioleaching of a low-grade nickel-copper sulfide by mixture of four thermophiles. Bioresour. Technol. 2014, 153, 300-306. [CrossRef] [PubMed]

11. Zeng, J.; Gou, M.; Tang, Y.Q.; Li, G.Y.; Sun, Z.Y.; Kida, K. Effective bioleaching of chromium in tannery sludge with an enriched sulfur-oxidizing bacterial community. Bioresour. Technol. 2016, 218, 859-866. [CrossRef] [PubMed]

12. Urík, M.; Bujdoš, M.; Milová-Žiaková, B.; Mikušová, P.; Slovák, M.; Matúš, P. Aluminium leaching from red mud by filamentous fungi. J. Inorg. Biochem. 2015, 152, 154-159. [CrossRef] [PubMed]

13. Rastegar, S.O.; Mousavi, S.M.; Shojaosadati, S.A.; Sarraf Mamoory, R. Bioleaching of V, Ni, and Cu from residual produced in oil fired furnaces using Acidithiobacillus ferrooxidans. Hydrometallurgy 2015, 157, 50-59. [CrossRef]

14. Kermer, R.; Hedrich, S.; Bellenberg, S.; Brett, B.; Schrader, D.; Schönherr, P.; Köpcke, M.; Siewert, K.; Günther, N.; Gehrke, T.; et al. Lignite ash: Waste material or potential resource-Investigation of metal recovery and utilization options. Hydrometallurgy 2017, 168, 141-152. [CrossRef]

15. Li, M.; Wei, C.; Fan, G.; Wu, H.; Li, C.; Li, X. Acid leaching of black shale for the extraction of vanadium. Int. J. Miner. Process. 2010, 95, 62-67. [CrossRef]

16. Dopson, M.; Lövgren, L.; Boström, D. Silicate mineral dissolution in the presence of acidophilic microorganisms: Implications for heap bioleaching. Hydrometallurgy 2009, 96, 288-293. [CrossRef]

17. Abhilash; Pandey, B.D. Bioreactor leaching of uranium from a low grade Indian silicate ore. Biochem. Eng. J. 2013, 71, 111-117. [CrossRef]

18. Anjum, F.; Shahid, M.; Akcil, A. Biohydrometallurgy techniques of low grade ores: A review on black shale. Hydrometallurgy 2012, 117-118, 1-12. [CrossRef]

19. Štyriaková, I.; Bhatti, T.M.; Bigham, J.M.; Štyriak, I.; Vuorinen, A.; Tuovinen, O.H. Weathering of phlogopite by Bacillus cereus and Acidithiobacillus ferrooxidans. Can. J. Microbiol. 2004, 50, 213. [CrossRef] [PubMed] 
20. Bhatti, T.M.; Bigham, J.M.; Vuorinen, A.; Tuovinen, O.H. Weathering of phlogopite in simulated bioleaching solutions. Int. J. Miner. Process. 2011, 98, 30-34. [CrossRef]

21. Bhatti, T.M.; Bigham, J.M.; Vuorinen, A.; Tuovinen, O.H. Weathering of biotite in Acidithiobacillus ferrooxidans cultures. Geomicrobiol. J. 2011, 28, 130-134. [CrossRef]

22. Mishra, D.; Kim, D.J.; Ralph, D.E.; Ahn, J.G.; Rhee, Y.H. Bioleaching of spent hydro-processing catalyst using acidophilic bacteria and its kinetics aspect. J. Hazard. Mater. 2008, 152, 1082-1091. [CrossRef] [PubMed]

23. Rasoulnia, P.; Mousavi, S.M. Maximization of organic acids production by Aspergillus niger in a bubble column bioreactor for $\mathrm{V}$ and $\mathrm{Ni}$ recovery enhancement from power plant residual ash in spent-medium bioleaching experiments. Bioresour. Technol. 2016, 216, 729-736. [CrossRef] [PubMed]

24. Mirazimi, S.M.J.; Abbasalipour, Z.; Rashchi, F. Vanadium removal from LD converter slag using bacteria and fungi. J. Environ. Manag. 2015, 153, 144-151. [CrossRef] [PubMed]

25. Liao, M.; Zhang, X.; Zhang, M.; Deng, R.; Zeng, Z. Study on the bioleaching conditions of vanadium from vanadium-bearing stone coal by Acidthiobacillus ferrooxidans. Fine Chem. 2015, 32, 144-148. (In Chinese)

26. Hu, Y.J.; Zhang, Y.M.; Bao, S.X.; Liu, T. Effects of the mineral phase and valence of vanadium on vanadium extraction from stone coal. Int. J. Miner. Metall. Mater. 2012, 19, 893-898. [CrossRef]

27. Chinese National Standard: GB/T 8704.5; Ferrovanadium-Determination of Vanadium Content-The Ammonium Ferrous Sulfate Titrimetric Method and the Potentiometric Titrimetric Method; Standard Press of China: Beijing, China, 2007. (In Chinese)

28. Chinese National Standard: HJ/T 345; Water Quality Betermination of Iron-Phenanthroline Specterophotometry; Standard Press of China: Beijing, China, 2007. (In Chinese)

29. Pradhan, D.; Mishra, D.; Kim, D.J.; Ahn, J.G.; Chaudhury, G.R.; Lee, S.W. Bioleaching kinetics and multivariate analysis of spent petroleum catalyst dissolution using two acidophiles. J. Hazard. Mater. 2010, 175, 267-273. [CrossRef] [PubMed]

30. Bhatti, T.M. Bioleaching of organic carbon rich polymetallic black shale. Hydrometallurgy 2015, 157, $246-255$. [CrossRef]

31. Leiviskä, T.; Khalid, M.K.; Sarpola, A.; Tanskanen, J. Removal of vanadium from industrial wastewater using iron sorbents in batch and continuous flow pilot systems. J. Environ. Manag. 2017, 190, 231-242. [CrossRef] [PubMed]

32. Blackmore, D.P.T.; Ellis, J.; Riley, P.J. Treatment of a vanadium-containing effluent by adsorption/coprecipitation with iron oxyhydroxide. Water Res. 1996, 30, 2512-2516. [CrossRef]

33. Roccaro, P.; Vagliasindi, F.G.A. Coprecipitation of vanadium with iron(III) in drinking water: A pilot-scale study. Desalin. Water Treat. 2015, 55, 799-809. [CrossRef]

34. Ahoranta, S.H.; Kokko, M.E.; Papirio, S.; Özkaya, B.; Puhakka, J.A. Arsenic removal from acidic solutions with biogenic ferric precipitates. J. Hazard. Mater. 2016, 306, 124-132. [CrossRef] [PubMed] 